\title{
Actions for adaptation and mitigation to climate change: Madrid case study
}

\author{
Acciones para la adaptación y mitigación del cambio climático: El caso de Madrid
}

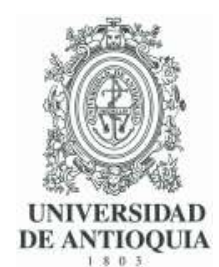

\author{
Valentina Oquendo-Di Cosola (D) ${ }^{1} 2^{*}$, Jorge Adán Sánchez-Reséndiz (D)2 ${ }^{2}$, Lorenzo Olivieri (iD)², Francesca \\ Olivieri (iD) 1,2 \\ ${ }^{1}$ Departamento de Construcción y Tecnología Arquitectónicas, ETS Arquitectura de Madrid, Universidad Politécnica de \\ Madrid. Avda. Juan de Herrera, 4. C. P. 28040. Madrid, España. \\ ${ }^{2}$ Centro de Innovación en Tecnología para el Desarrollo Humano (itdUPM). ETS Ingeniería Agronómica, Alimentaria y de \\ Biosistemas. Av. Complutense s/n, Ciudad Universitaria. C. P. 28040. Madrid, España.
}

\section{CITE THIS ARTICLE AS:}

V. Oquendo, J. A Sánchez, L. Olivieri and F. Olivieri. "Actions for adaptation and mitigation to climate change: Madrid case study", Revista Facultad de Ingeniería Universidad de Antioquia, no. 101, pp. 84-99, Oct-Dec 2021. [Online].

Available: https :

//www.doi.org/10.17533/

udea.redin. 20200795

\section{ARTICLE INFO:}

Received: December 09, 2019 Accepted: July 17, 2020

Available online: July 17, 2020

\section{KEYWORDS:}

Nature-based solutions; sustainable cities; innovation

Soluciones basadas en la naturaleza; sostenibilidad; innovación
ABSTRACT: Systemic innovation must be the driving force behind actions to transform cities to address climate change. It includes transformations of environmental, social, economic, financial, technical, regulatory, and governance nature, supporting the permanent change of cities. Nature-Based Solutions (NBS), can be part of the tools to address the challenges ahead. This research aims to define a framework of action in cities for the implementation of NBS, demonstrating the importance of quantifying its benefits in environmental and socio-economic terms, to boost public policy design and investment in this field. This work is divided into two parts. The first part, analyses some of the European measures in the field of sustainable development in cities, focusing the research on the case of Madrid. And in the second part, some case studies are presented to reflect the measures and actions taken to promote the implementation of NBS in the city of Madrid. As a result, the potential levers of change for the implementation of NBS are identified, highlighting the importance of quantifying their effects to demonstrate the potential value that can be generated within cities.

RESUMEN: La innovación sistémica debe ser el motor que potencie las acciones orientadas a la transformación de las ciudades frente al cambio climático. Esta comprende transformaciones de carácter ambiental, social, económico, financiero, técnico, regulatorio y de gobernanza, que soporten el cambio definitivo en las ciudades. Las Soluciones Basadas en la Naturaleza (SBN) pueden ser parte de las herramientas para hacer frente a los desafíos a los que nos enfrentamos. El objetivo de esta investigación es definir un marco de acción en las ciudades para la implementación de las SBN, que demuestre la importancia de cuantificar sus beneficios en términos medioambientales y socioeconómicos, para el impulso del diseño de políticas públicas y la inversión en este campo. Este trabajo se divide en dos partes. En la primera parte, se analizan algunas de las medidas europeas en el ámbito del desarrollo sostenible en ciudades, centrando la investigación en el caso de Madrid. Y en la segunda parte, se exponen algunos casos prácticos para reflejar las medidas y acciones tomadas con la finalidad de impulsar la implementación de las SBN en la ciudad de Madrid. Como resultado, se identifican potenciales palancas de cambio para la implementación de las $\mathrm{SBN}$, dentro de las que destaca la importancia de cuantificar sus efectos para demostrar el valor potencial que se puede generar en las ciudades. 


\section{Introduction}

\subsection{Innovation through Sustainable Development Goals (SDGs)}

In 2015, 193-member states of the United Nations unanimously adopted the Agenda 2030 for Sustainable Development, made up of 17 Sustainable Development Goals (SDGs), and 169 goals to be achieved by 2030 [1]. These universally applicable goals set quantitative results in the three dimensions of sustainable development: social, economic, and environmental. They address critical issues related to human development such as energy poverty, climate change, economic development, protection of ecosystems, and cities. However, this agenda has been more ambitious and comprehensive than the previous ones, since it integrates dimensions that had been absent until now, such as governance, gender equity, and peace.

The international community, through the 2030 agenda, has changed its vision of how to tackle development problems. This approach implies taking on challenges on a global scale in a much more complex and interdependent world, which sometimes implies significant resource management. Although, it requires the collaboration of different actors in society - governments, citizens, investors, civil society - who seeks to connect demand with action. The transition to a more desirable world for all should go beyond independent initiatives and partial approaches and must be characterized by a new narrative that encompasses the growth of the entire economy [2].

Cities play a fundamental role in the path to achieve Sustainable Development Objectives. Any vision of the future that seeks to design sustainable scenarios must consider the social, economic, and environmental aspects involved. By 2050, it is projected that more than half of the world's population will live in cities, accounting for $90 \%$ of urban expansion in developing countries [3]. The interpretation of these data leads to estimate that the growth rate of cities will be 1 million people per week; becoming one of the main challenges of the 2030 agenda, since population growth is intrinsically related to energy consumption and pollutant emission.

Cities occupy only $3 \%$ of the earth's surface and account for $80 \%$ of energy consumption and around $75 \%$ of the planet's $\mathrm{CO}_{2}$ emissions. Many cities are also highly vulnerable to climate change, and natural disasters mainly due to their location, so strengthening adaptation and mitigation to the vast consequences of massive city development is crucial to avoid negative socio-economic impacts.

With the Agenda 2030 and the Sustainable Development
Goals, countries have committed themselves to set a goal for prosperity, people, peace, and partnerships in favour of moving towards a stable and long-term development scenario. To achieve this, not only are technological developments or scientific advances needed, transformations are needed that develop technologies capable of promoting public and private investments and stimulating governance mechanisms.

In response to this scenario, the Sustainable Development Solutions Network, in its report, 2019 [4], refers to six main changes to achieve the SDGs, based on two cross-cutting principles. The first is related to governments and the need to ensure that each change promoted is designed by and to encourage equity and social inclusion, applying particularly to public services and infrastructure. The second argues that any transformation must reduce humanity's vulnerability, i.e., the environmental footprint, resource use, and pollution caused by human well-being.

Among the 6 transformations, the proposal of the SDG 11 stands out: Sustainable Cities and Communities, which contemplates within its action the investment in green infrastructure in cities, towns, and communities that contribute to face climate change. Although this is a specific objective, its impacts indirectly affect all the SDG targets, mainly those related to transport, urban development, and water resources.

The development of public policy and increasing research has demonstrated the milestone cities represent in the global urban transformation and in the development of innovative solutions. Proof of this has been the implementation of the New Urban Agenda and the Spanish Urban Agenda, as well as statements such as those of sociologist and economist Saskia Sassen who states that "cities will be more important than states" [5].

In the field of research and its main funding programmes at the European level (Horizon Europe) and in Spain (State Research Plan 2021 - 2027), the focus is on systemic innovation. This approach is being promoted by the European Commission [6, 7] and has been theorised by Mariana Mazzucato [8], professor of Economics of Innovation and Public Value at University College London (UCL), who states that on the basis of innovative policies, oriented towards one or more specific missions, it is possible to define ambitious, long-term political objectives. These missions oriented towards sustainability in the urban environment will require investment in areas such as energy, transport, nutrition, health, and waste reduction. This approach offers a massive opportunity to increase the impact of research and innovation, capture the collective imagination, and make real progress in complex challenges, whether it is to achieve lower pollution levels 
in congested cities, have access to digital technologies that improve public services, or better treatments for the sick.

A crucial element within this theory of innovation in cities is the culture that supports experimentation, risk-taking, original, and creative thinking aimed at finding new solutions to existing problems. To this end, it requires interdisciplinary academic work, the intersection between knowledge sectors, a collaboration between different segments of the industry, alliances between the public-private sector and civil society organizations, to identify cross- cutting solutions to complex problems.

Due to their complexity and the fundamental role they play in the transition towards a more desirable future, cities offer us an extraordinary scenario to accommodate experimental research based on interdisciplinary approaches. As cities are places where negative impacts occur from a social and environmental point of view, there are issues such as atmospheric pollution and climate change, which have a direct incidence of cardiorespiratory diseases, rising temperatures, among others. In contrast, cities by their very nature can favour the search and joint identification of solutions to these problems.

According to weather forecasts and reports, the long-term climate will be characterized by a predominance of extreme weather events, as well as a general increase in temperatures and a decrease in precipitation. Addressing current needs for adaptation and mitigation of climate change impacts is therefore critical. Along these lines, nature-based solutions, among many others, are shown to be solutions that promote the transition to healthier, more resilient, sustainable, inclusive, and friendly city models.

This article is adapted from the work done for the ICSC-CITIES 2019 congress "Nature-Based Solutions for Cities Resilience: opportunities for action in Madrid" [9]. In this work, we have deepened in one of the practical cases, specifically, the quantification of the effects of the vegetal facades installed in the building of the Innovation in Technology for Human Development Centre (itdUPM).

\subsection{Nature-Based Solutions: goal and challenges}

Climate change is affecting ecosystems, and, in this scenario, future environmental challenges are expected to increase [10]. The densification of cities, the degradation of soils, and natural areas are part of the challenges we face today. These processes lead to the loss of biodiversity and the biological processes necessary for the survival of the planet.
If these challenges are seen as opportunities for innovation, Nature-Based Solutions can achieve biodiversity conservation, but also bring environmental, economic, and social benefits, and foster climate change mitigation and adaptation [11].

The term Nature-Based Solution emerges around the year 2000 as a perspective of the relationship between people and nature, focusing specifically on the use of nature to address social and environmental challenges such as climate change. The European Commission defines them as "those that can turn nature into opportunities for social, economic and environmental innovation" [11]. However, the affirmation of the concept as a means of providing solutions to the problems posed by climate change is very recent [12].

NBS are solutions capable of interpreting complex processes of nature, such as the absorption of carbon dioxide, the treatment, and management of rainwater, the fixation of atmospheric particles, among others, to reduce environmental risks and achieve human well-being. Therefore, maintaining and improving the natural capital is the principle of this type of solution.

The benefits provided by nature in urban spaces have always been related to environmental and social sustainability. This concept has evolved as a public policy on environmental issues has been transformed, shaping research programmes such as the European Union's Framework Programmes for Research (Horizon 2020) [13], which incorporate narratives on ecosystem services that respond, among other things, to the Sustainable Development Goals [1]. The current calls allocate an important part of the funds to the recovery of the urban ecosystem, through green infrastructure, seeking to promote the monitoring of pilot experiences to quantify their benefits and contribute to pilot-based decision-making in cities [14].

According to a group of experts from the European Commission [11], nature-based solutions should be developed within the framework of 4 main objectives and 7 actions in the field of research and innovation. These include "(I) urban regeneration through nature-based solutions; (II) nature-based solutions for improving well-being in urban areas; (III) establishing naturebased solutions for coastal resilience; (IV) multi-function nature-based watershed management and ecosystem restoration; (V) nature-based solutions for increasing the sustainable use of matter and energy; (VI) nature-based solutions for enhancing the insurance value of ecosystems; (VII) increasing carbon sequestration through nature-based solutions". These actions would lead to the promotion of international cooperation in the 
development of sustainable solutions that would help Europe achieve its objectives of sustainable urbanisation, adaptation, and mitigation of climate change, risk management, and resilience.

Taking advantage of the impulse of big problems to bet on change seems to be the way. Facing current challenges based on studies already carried out on how nature works and how many benefits are, including innovative developments of alliances between governments, companies, and investors. There is today a real awareness of the value of nature, and the growing number of international organizations, policy initiatives for conservation and sustainability is proof of this.

\section{Evaluating the effectiveness of Nature-Based Solutions}

The impact and effectiveness of nature-based solutions can be analysed from three main concepts including quantification of the benefits obtained, mapping and evaluation of the profitability of these solutions, and finally the capacity to integrate different sectors of society and assimilate it into their city management policies.

This paper evaluates the effectiveness of NBS from three fundamental aspects: the monitoring of their behaviour, the capacity to provide profitable ecosystem services, and finally, the importance it has in the framework of action of the decision-makers in the cities. The final aim is to build a comprehensive narrative on their capacity for systemic transformation in response to the challenges faced by cities, demonstrating the value of quantifying performance and benefits.

\subsection{Monitoring and analysis}

One of the most important challenges of NBS is to make its effects become visible. They have a number of benefits designed to produce changes in the context in which they are found, varying in scale from a micro-level of the building, a meso-level of an entire city or country, or a macro-level of the entire planet [15]. One possible way to quantify their effects may be to evaluate their impact on a given space, through the use of indicators.

Therefore, taking into account the different scales of action and capabilities of these solutions it is possible to assess the impact through:

- Increase of green areas for the evaluation of, carbon absorption and improvement of air quality [16-20], reduction of temperatures [21-25], and acoustic absorption [26-30];
- Increase in the use of façades and plant covers to mitigate the effect of urban heat island, through the management of shade and the effect of evapotranspiration of plants and substrate [24, 31-37].

- Reduction of emissions and energy consumption through the study of solutions that contribute to the energy balance of buildings [21, 38-42].

\subsection{Economic valuation: NBS as a business model}

Nature-based solutions are a form of eco-innovation that seeks to address climate change from the mitigation and adaptation of its effects on cities and people, such as improving air quality [1-3], reducing biodiversity loss [4-6] , reducing the urban heat island effect [7-9], among others. Part of these solutions has to do with green infrastructure that adapts to the current grey infrastructure, such as green facades and roofs, rainwater recycling systems, parks, and forests. These can provide value to society, whether economic, environmental, or social.

From a socio-economic perspective, NBS can be interpreted as a natural capital, which provides services to current ecosystem problems [43]. These services can be classified into three categories, according to The Economics of Ecosystems and Biodiversity (TEEB) [44]. First, they provide "provisioning services" such as food, biomass, clean water, and medical resources. Second, they provide "regulating services" such as temperature regulation, air quality, biodiversity protection, noise reduction, atmospheric carbon reduction, and water purification. Finally, they provide "cultural services" through recreation in public spaces and the psychological well-being of people.

Innovation as a business model has been widely studied [45-47], and in its development proposes three main areas: (I) the value proposition for customers in the form of service; (II) how the value is delivered, i.e., the partners; (III) and the component that captures the value, i.e., the revenues and costs.

These concepts translate into NBS, specifically, those related to buildings: facades and roofs, as well as those related to water management, can be framed in a sustainable business model.

An example of this is green roofs, which provide insulation and protection to buildings, which leads to maximizing energy efficiency. For the owner of a building, the investment in this type of solutions will be perceived in the reduction in expenses related to the conditioning of the internal spaces, as well as those of maintenance. 
Also, these solutions can use the building's water, heat, and organic waste to maintain themselves. This type of technology can be developed in the model of passive solutions for reducing energy consumption $[10,11]$, recycling rainwater [12], improving air quality [13], increasing biodiversity[5], among others. However, these benefits are difficult to capture through private investments, so their monitoring and quantification would establish a framework for profitability and investment.

Another important example would be the management of water flows in densely urbanized areas. Water management through NBS provides an alternative to prevent flooding in cities, as opposed to creating a grey infrastructure based on pipelines. Sustainable drainage systems can generate numerous benefits; however, the lack of quantification of these benefits becomes a barrier to diffusion in cities and adaptation by authorities.

One of the main obstacles in investing in green infrastructure is the economic return, and this is due to the lack of tools that capture the value and service they offer. The success of innovation through nature can go hand in hand with the quantification of its benefits and public-private investment.

\subsection{Policy implications}

The insertion of these solutions in cities depends to a great extent on a new model of governance, i.e., coordination between administrations is essential when it comes to tackling problems that affect society. This is proposed in the European Urban Agenda [48], through the establishment of global and integrated strategies that provide solutions to common challenges.

Part of these strategies could be materialized in the emergence of new organizations in the form of innovation laboratories driven by the local administration that allow prototyping and evaluating actions and solutions, that in turn, respond to current challenges and are developed in open collaboration with the citizenry. The development of technology and interdisciplinary collaboration can be transformed based on acceleration towards the resilience of cities.

There are several options through which policymakers at a local, regional, or national level can foster innovation through NBS in cities. Either through long-term funding, establishing an accounting framework for the services nature provides, such as, improving air quality, and developing public-private partnerships with incentives that benefit all actors: academic, business, and government.

Indicators such as the growth rate for jobs related to green infrastructure, access to energy from renewable sources, the percentage of the total area of green spaces, the reduction in insecurity rates linked to the recovery of degraded spaces, the levels of the population exposed to outdoor air pollution, wastewater treatment, the percentage of solid waste recycling, the proportion of renewable energy, and the investment capacity of public-private cooperation, can be instruments of public policies for quantifying the effectiveness of these solutions.

\section{Nature-Based Solutions in practice: the case of Madrid city}

Madrid is a city with a great deal of experience in innovation and transformation of its urban tissue, as well as in the development of public policies that respond to the economic and environmental commitments acquired at the European level. It has demonstrated this through its work towards a low-carbon, circular, ecosystem-friendly economy, which highlights NBS as a lever towards resilience in the face of climate change.

\subsection{Government and regulations}

Today, urban nature has taken on the role of an instrument for adapting the city to the effects of climate change. In the international context and at the European level, different cities are developing programmes for the integration of nature into urban contexts as a way of adapting cities to climate change [49-51].

Concerning these plans, the commitments made by Madrid City Council on climate change have been on the rise, demonstrating this through adherence to the European New Covenant of Mayor's initiative; the participation in the Paris Conference of the Parties (COP21); the adherence to international networks such as the network of cities for climate C40; and the development of concrete plans for the implementation of NBS and the improvement of air quality.

To identify the threats and vulnerability of the city of Madrid to climate change, the General Directorate for Sustainability and Environmental Control carried out an analysis [52], based on the Energy and Climate Change Plan for the city of Madrid - Horizon 2020. This identifies the main climate trends and the impacts derived which the city will have to face throughout this century. Including a decrease in rainfall, an increase in average monthly and annual temperatures, as well as an increase in the duration of heatwaves. These changes can affect public health and the loss of biodiversity. Since it not only increases air pollution but also diminishes water resources reserves and increases the risk of flooding from 
heavy rainfall.

To respond to these challenges, the Energy and Climate Change Plan establishes a strategic framework for developing a low-carbon city, which promotes energy efficiency and the use of renewable energies, the optimisation of municipal energy and environmental management, and the planning of adaptation to climate change.

The Madrid + Natural Plan was born out of the commitment to advance municipal policies [53]. To promote the development of green urban infrastructure, the programme was structured on three scales: the building, the neighbourhood, and the city, in such a way that the actions lead to specific and common objectives. These include improving the energy performance of buildings, regulating rainwater flow, making green spaces available, mitigating the urban heat island effect, improving air quality, and monitoring facilities to quantify the cost-benefit ratio, maintenance, and operation of these solutions.

Plan A: Air Quality and Climate Change Plan for the City of Madrid is part of this strategy, a tool for reducing air pollution, contributing to the prevention of climate change, and defining adaptation strategies [54]. It is structured in four key areas: sustainable mobility, urban regeneration, adaptation to climate change, public awareness, and collaboration with other administrations. It has an ecological vision of the city, both in terms of mobility and public awareness, and in the rehabilitation of buildings, public spaces, local energy production, water management, and the renaturation of the city.

In the context of the programmes and initiatives previously discussed, and with the assumption that the city needs to establish new models of relationship with the climate and the environment, we present below a series of case studies carried out in the city of Madrid and coordinated from the Universidad Politécnica de Madrid, establishing the main objective of introducing NBS as a tool for mitigating and adapting to climate change.

\subsection{Case studies}

The following are different research projects whose main objective is to quantify the effects on buildings and the urban environment of different nature-based solutions. The quantification was carried out through the use of predictive models, the use of specific computer tools, and the analysis of the data obtained.

It is important to note that the results presented here applied only to the city of Madrid. And although this type of solution can be extrapolated to other geographical contexts, as they are natural processes of exchange with the environment, the results and effectiveness of these will vary accordingly.

Several variables are analysed in detail:

- Energy efficiency

- To quantify, by monitoring and data analysis, the effect provided by vertical gardens on the indoor thermal conditions of a building.

- To quantify, by predictive models, the energy behaviour of façades and plant roofs, the effect that the installation of a plant roof and roof would provide on the internal thermal conditions of a building and its energy demand.

- Reduction of temperatures at street level

- To quantify the effect of different Nature-Based Solutions in reducing outdoor temperatures at street level during the warm season.

- Reduction of air pollutants

- To quantify the effect of a tower with vegetation in the absorption of polluting gases and the capture of suspended particles.

- Sustainable use of rainwater in the built environment

- To quantify the effect of a circular system for integrated water management in built environments on the temporary retention of runoff water and the elimination of pollutants.

\section{Energy efficiency through analysis of experimental data: vertical gardens on itdUPM}

The study is being carried out in the maintenance building of the Escuela Técnica Superior de Ingeniería Agronómica, Alimentaria y de Biosistemas (ETSIAAB) of the Universidad Politécnica de Madrid, the current headquarters of the Centro de Innovación en Tecnología para el Desarrollo Humano (itdUPM).

In 2016, the building was renovated to become the headquarters of the itdUPM and was set up as an experimental building to promote sustainable development within a programme of new strategies and technologies (Figure 1).

The building has a rectangular floor plan and measures approximately $21.38 \mathrm{~m} \times 9.35 \mathrm{~m}$. There are two floors: basement and ground floor, each with $199,90 \mathrm{~m}^{2}$ built, with a height of $4,70 \mathrm{~m}$. The total area of the building is $399,80 \mathrm{~m}^{2}$. 
The building's requalification proposal is based on the integration of a vegetal envelope that occupies part of the south, east and west facades. The façade system is based on a recyclable plastic module belonging to the continuous plant façade systems with an organic substrate. This system allows savings in water consumption and low fertilizer use.

The metal skin has been made through a ventilated façade in three of the four walls of the building (south, east, and west), and consists of modules $2.4 \mathrm{~m}$ long $\times$ $0.6 \mathrm{~m}$ high, supported on vertical uprights. These uprights placed every $2.4 \mathrm{~m}$, do not rest on the ground but are anchored to the envelope of the existing building using metal plates screwed to the wall. Each upright rest at three points on the wall. This metal façade, with its structure, allows the vertical garden modules to be placed on top of it, making it very quick to install. The vertical garden modules are made up of pre-cultivated panels fixed to the metal enclosure. These façades currently cover an area of $11.25 \mathrm{~m}^{2}$ on the south façade, $6.25 \mathrm{~m}^{2}$ on the east façade, and $10 \mathrm{~m}^{2}$ on the west façade.

The system used is a commercial product Biofiver [55], which has the following characteristics:

- Size: $50 \mathrm{~cm} \times 50 \mathrm{~cm} \times 10 \mathrm{~cm}$

- Weight (without plants): $2 \mathrm{Kg}$

- Number of floors $/ \mathrm{m}^{2}: 48$

- Static system: simple anchorage

- Irrigation system: integrated exudate pipe

- Module material: recyclable polyethylene

- Substrate: organic (coconut, peat, humus clays)

It is composed of two three-dimensional polyethylene structures, including a hydrophilic layer for the distribution and drainage of the irrigation water. One of the structures is filled with a substrate for cultivation, and the other remains empty, creating a hollow space for air circulation. The irrigation system is internal and is done through self-compensated dripping, which means that the water is always in circulation generating a humid environment.

\section{Reductions of temperatures at street level: renaturation of Matadero}

This second case study is part of the "Matadero Acción Mutante" project an initiative carried out by Matadero in collaboration with a group of researchers from the UPM, the Sub Directorate-General for Energy and Climate Change, and the Directorate General for Intervention in Urban Landscape and Cultural Heritage of the Madrid City Council and other agents such as architects, engineers,

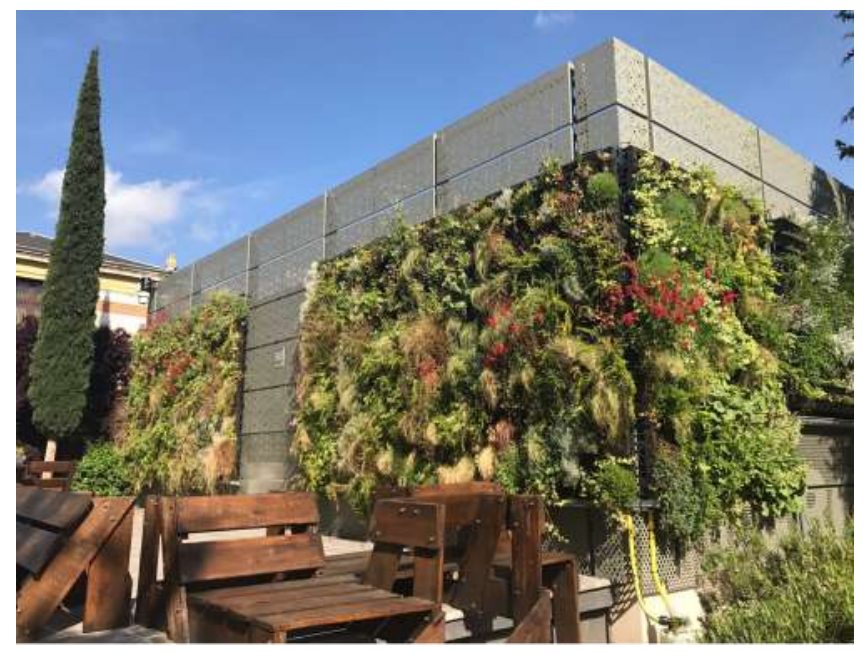

Figure 1 Headquarter of Innovation and Technology for Development Centre (itdUPM)

artists, botanists. This aims to raise awareness of the environmental crisis with strategies for mitigation and adaptation to climate change and through the relationship culture-nature.

The exterior space of the enclosure occupies 34330 $\mathrm{m}^{2}$, so it is significant to think about treating these spaces that form part of the complex. The spaces without vegetation and shade suffer enormously from extreme temperatures and especially the heat waves that are occurring more and more frequently in Madrid. It is for this reason that Matadero has become a case study to apply Nature-Based Solutions and thus test responses to adapt to climate change while transforming Matadero in a friendlier and fresher space. The solutions based on nature will be the result of a creative process involving five artists from different parts of the world.

As a first step of the work, in the summer of last year, five sensors were installed in different external spaces of Slaughterhouse or near it for the measurement of temperatures and humidity of the air in the current state before the interventions of urban naturalization (Figure 2) The sensors used were the HOBO MX2301A Temperature/RH Data Logger [56].

\section{Reduction of air pollutants: modules for urban air cleaning (MUAC)}

This case study is based on the installation and monitoring of two identical experimental prototypes of the MUAC (Modules for Urban Air Cleaning) tower with vegetation (Figure 3). The first was installed in October 2018 in the vicinity of the former maintenance building of the Escuela Técnica Superior de Ingeniería Agronómica, Alimentaria y de Biosistemas (ETSIAAB) of the Universidad 

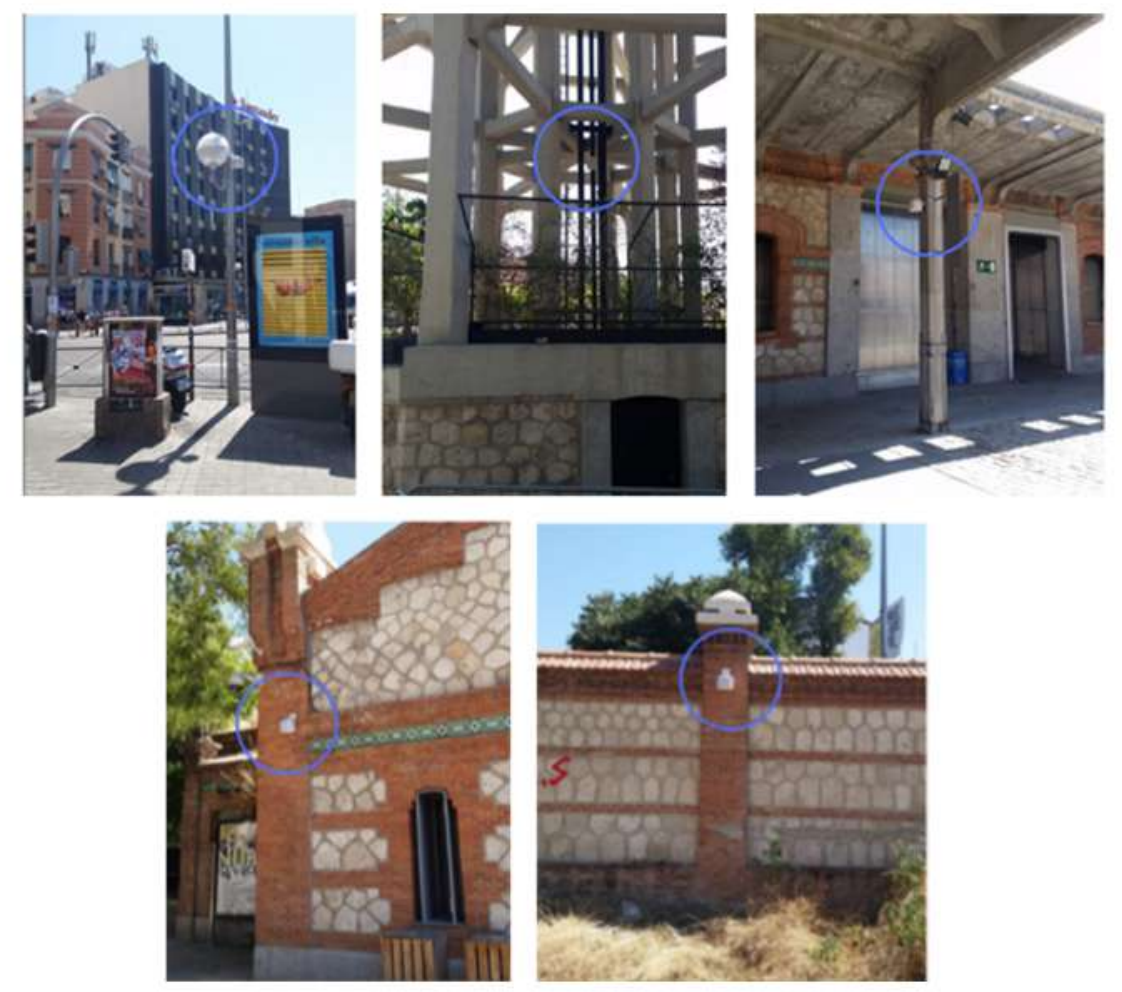

Figure 2 Location of the sensors, from the top right clockwise: Plaza de Legazpi, Plaza de acceso, Calle Matadero, Casa del Lector (north access), "No huerto"
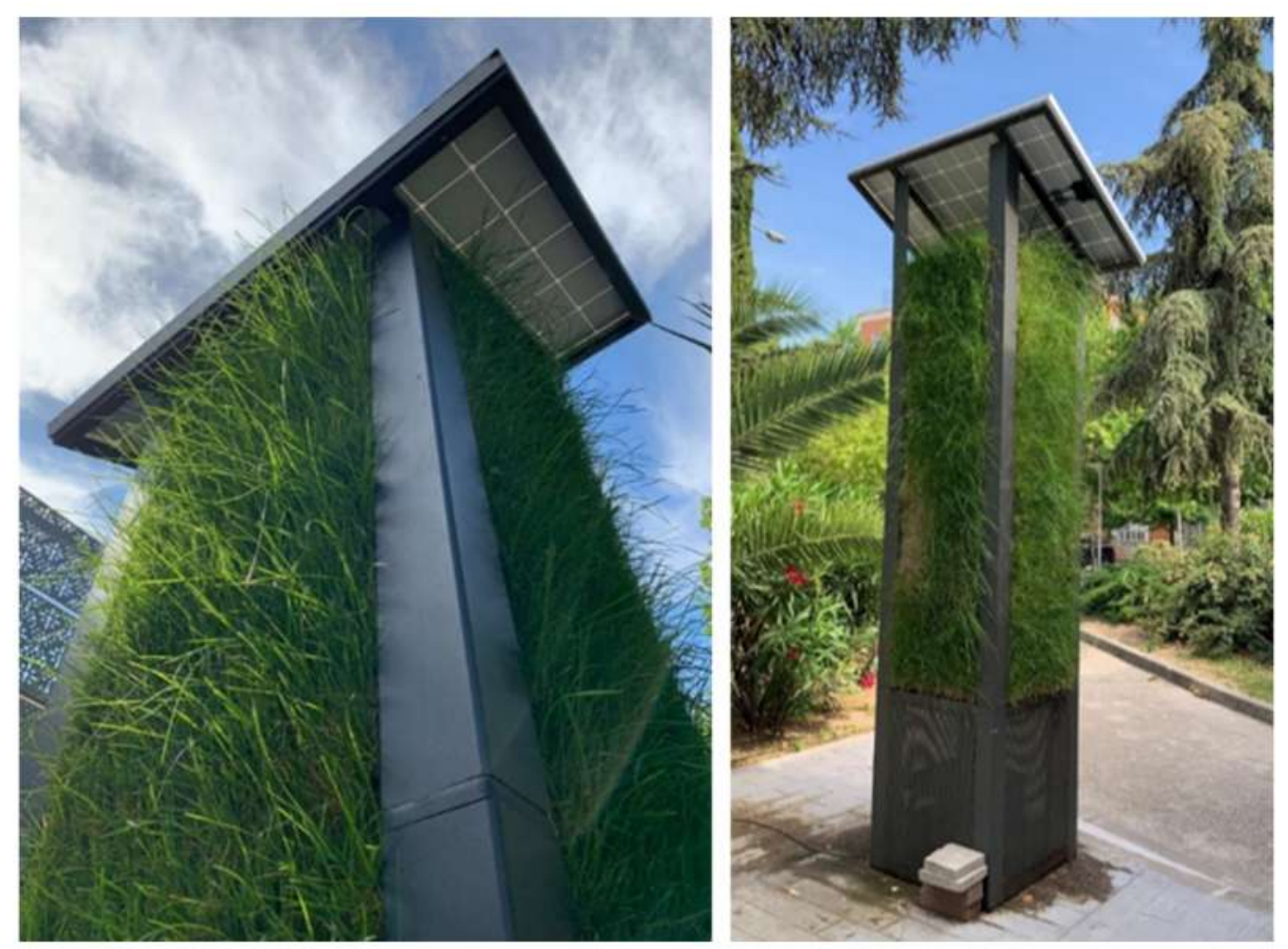

Figure 3 A prototype of the MUAC installed at the entry of the itdUPM headquarters 
Politécnica de Madrid, current headquarters of the Centro de Innovación en Tecnología para el Desarrollo Humano (itdUPM); and the second will be installed in the vicinity of the Escuela Técnica Superior de Ingenieros Industriales (ETSII) of the Universidad Politécnica de Madrid in autumn 2019.

MUAC vegetation tower is an air decontamination system that reproduces the biological and microbiological purification processes carried out in forests. The tower is $2.8 \mathrm{~m}$ high and has a square floor area of $0.7 \mathrm{~m}$ on each side, with a total surface area of $0.49 \mathrm{~m}^{2}$. It consists of 16 plant panels from the Biofiver system.

The purification of the air is carried out outside and inside the tower. Outdoors, the leaves capture and absorb suspended particles $\left(\mathrm{PM}_{2.5} / \mathrm{PM}_{10}\right)$, as well as generate an exchange of gases $\left(\mathrm{CO}_{2}\right.$ for $\left.\mathrm{O}_{2}\right)$ through the process of photosynthesis. In the interior, the air is filtered through a process where the roots and the microorganisms that inhabit the substrate absorb and feed themselves with polluting gases such as $\mathrm{CO}_{\mathrm{x}}, \mathrm{NO}_{\mathrm{x}}, \mathrm{O}_{3}$, or $\mathrm{SO}_{\mathrm{x}}$.

This system has been designed to easily adapt to different types of environments and climates, using native vegetation. Furthermore, the MUAC is equipped with an autonomous energy system that, through a photovoltaic panel and a storage battery, allows it to operate 24 hours a day, even in conditions where there is no connection to the electricity supply. Electrical energy is used to power both the irrigation system and the air circulation system inside the tower.

The two vegetation towers are equipped with two types of sensors for the measurement of suspended particles and polluting gases. These are the Uhooair sensors, which measure $\mathrm{NO}_{\mathrm{x}}, \mathrm{CO}_{\mathrm{x}}, \mathrm{COV}_{\mathrm{x}}, \mathrm{O}_{3}, \mathrm{PM}_{2.5}$, etc. (Table 1) and Purpleair sensors, which measure particles in suspension PM 0.3, 0.5, 1.02 .5 and $10 \mu \mathrm{m}$ (Table 2) tower, where the composition of the air is measured after the decontamination process.

The monitoring period shall be one year llimited to the lifetime of the measurement sensors). The data obtained will be used to measure the efficiency of the system, in addition to allowing us to estimate the impact that the implementation of towers would have on the urban fabric of cities.

\section{Sustainable use of rainwater in the built environment: Bluebloqs circular water system}

This last case study consists of the installation and monitoring of the Bluebloqs system. It is an innovative solution developed by the Dutch Start-up Field Factors for the management and sustainable use of rainwater in the built environment, which integrates natural techniques for the retention, treatment, storage and reuse of rainwater in a circular system of flexible implementation in urban design, with the aim of restoring the natural water cycle in cities.

Bluebloqs biofilter is a modular system that combines hybrid technology using biological purification, and the proven purification power of wetland plants (68-72), as well as mineral purification using sand filters (73-77) to achieve highly efficient water treatment (Figure 4). Bluebloqs integrates natural purification processes in a controlled environment, eliminating the need for large infrastructures or chemical substances.

The system has distribution channels and water level and flows control mechanisms. The biofilter can be adapted to remove specific contaminants: organic matter, metals, and high levels of nitrogen usually found in runoff water (samples of water quality are currently analysed weekly, with results showing purification of more than $90 \%$ of impurities). The biofilter is optimized to work in combination with technologies for water injection and extraction in aquifers, guaranteeing high levels of water quality to comply with infiltration regulations and avoiding obstruction of facilities.

Bluebloqs presents a comprehensive solution for multiple challenges in water management. First, it aims to prevent flooding. The urban space is full of buildings and infrastructure that limit the infiltration of rainwater into the terrain. Bluebloqs makes use of the natural capacity of the subsoil to purify and store excess rainwater. This slows runoff infiltrates surface water and recharges groundwater levels, providing the retention capacity needed to prevent flooding.

Secondly, it contributes to combating drought. Longer periods of drought, loss of infiltration, and exponential population growth force us to use drinking water differently. With Bluebloqs, rainwater can be used when it is needed most: in times of drought. By creating a high-quality local water source, purified water stored in the subsoil can be used for numerous applications, including water parks, sports fields, and gardens, combating the heat, stabilizing surface waters, and industrial processes.

Finally, improving water quality. Urban currents carry pollutants present on the surface and in the environment, especially in large cities. Pavements, roofs, and the use of the environment emit pollutants that include metals, nutrients, and pathogens. To make safe use of rainwater and avoid the dispersion of pollutants, it must be treated. Bluebloqs makes use of natural purification systems, removing organic matter, solids, metals, and nitrogen 
Table 1 Actual measurement values by sensor type (Source https://uhooair.com)

\begin{tabular}{|c|c|c|c|c|c|c|c|c|c|}
\hline & Temperature & $\mathbf{R H}$ & $\mathrm{PM}_{2.5}$ & $\mathrm{CO}_{2}$ & TVOC & CO & NO & $\begin{array}{c}\text { Air } \\
\text { Pressure }\end{array}$ & $\mathrm{O}_{3}$ \\
\hline Units & ${ }^{\circ} \mathrm{C} /{ }^{\circ} \mathrm{F}$ & $\%$ & $\mu \mathrm{g} / \mathrm{m}^{3}$ & ppm & $\mathrm{ppb}$ & $\mathrm{ppm}$ & $\mathrm{ppb}$ & mBar & $\mathrm{ppb}$ \\
\hline \multirow{3}{*}{ Range } & $-40^{\circ} \mathrm{C} /-40^{\circ} \mathrm{F}$ & 0 & 0 & 400 & 0 & 0 & 0 & 300 & 0 \\
\hline & to & to & to & to & to & to & to & to & to \\
\hline & $85^{\circ} \mathrm{C} / 185^{\circ} \mathrm{F}$ & 100 & 200 & 10.000 & 1000 & 1000 & 1000 & 1100 & 1000 \\
\hline Resolution & $0.1^{\circ} \mathrm{C}$ & $1 \%$ & $0.1 \mu \mathrm{g} / \mathrm{m}^{3}$ & $1 \mathrm{ppm}$ & $1 \mathrm{ppb}$ & $1 \mathrm{ppm}$ & $1 \mathrm{ppb}$ & $1 \mathrm{mBar}$ & $1 \mathrm{ppb}$ \\
\hline Tolerance & $\pm 0.3^{\circ} \mathrm{C}$ & $\pm 3 \%$ & $\begin{array}{c} \pm 20 \mu \mathrm{g} / \mathrm{m}^{3} \\
\quad \text { or } \\
\pm 20 \%\end{array}$ & $\begin{array}{c} \pm 50 \text { ppm } \\
\text { or } \\
\pm 3 \%\end{array}$ & $\begin{array}{c} \pm 5 \%, \text { based } \\
\text { on the types } \\
\text { of VOC in } \\
\text { the air }\end{array}$ & $\begin{array}{l} \pm 10 \\
\mathrm{ppm}\end{array}$ & $\pm 5 \%$ & $\begin{array}{c} \pm 1 \\
\mathrm{mBar}\end{array}$ & $\pm 5 \%$ \\
\hline
\end{tabular}

Table 2 Actual measurement values of PM particles (Source https : //www2.purpleair.com)

\begin{tabular}{ll}
\hline \multicolumn{2}{c}{ Laser Particle Counters } \\
\hline Type & (2) PS5003 \\
Range of measurement & $0.3,0.5,1.0,2.5,5.0, \& 10 \mu \mathrm{m}$ \\
Counting efficiency & $50 \%$ at $0.3 \mu \mathrm{m} \mathrm{\&} \mathrm{98 \%} \mathrm{at} \geq 0.5 \mu \mathrm{m}$ \\
Effective range $\left(\mathrm{PM}_{2.5}\right.$ standard) * & 0 to $500 \mu \mathrm{g} / \mathrm{m}^{3}$ \\
Maximum range $\left(\mathrm{PM}_{2.5}\right.$ standard) * $^{*}$ & $\geq 1000 \mu \mathrm{g} / \mathrm{m}^{3}$ \\
Maximum consistency error (PM 2.5 & $\pm 10 \%$ at 100 to $500 \mu \mathrm{g} / \mathrm{m}^{3} \&$ \\
standard) & $\pm 10 \mu \mathrm{g} / \mathrm{m}^{3}$ at 0 to $100 \mu \mathrm{g} / \mathrm{m}^{3}$ \\
Standard Volume & $0.1 \mathrm{Litre}$ \\
Single response time & $\leq 1$ second \\
Total response time & $\leq 10$ seconds \\
\hline
\end{tabular}

levels typically found in urban runoff.

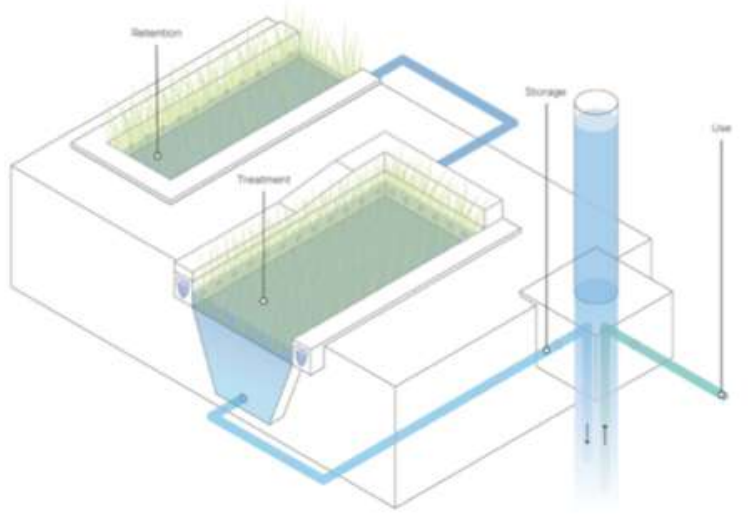

Figure 4 Water cycle in the Bluebloqs system

\section{Quantification of effects: the case of the innovation and technology for human development centre (itdUPM)}

The vegetal facades installed in the itdUPM are monitored to study the performance and its influence on the improvement of the environmental conditions and the energy consumption of the building.

There is a total of eight sensors on the façade, four in each orientation. Of these four, one pair measures the surface temperatures of the vertical garden ( $A$ and $B, E$ and F), while the other pair is placed on the metal skin ( $C$ and $D, G$ and $H$ ). Both pairs of sensors measure the surface temperature on the envelope and the immediate wall (Figure 5).

\subsection{Local climate conditions in summer}

Madrid's climate is in a semi-arid to Mediterranean transition. Due to its altitude of $650 \mathrm{~m}$ above sea level, great differences in temperatures are experienced between winter and summer. Summers are usually hot, with average temperatures above $25^{\circ} \mathrm{C}$ in July, with 


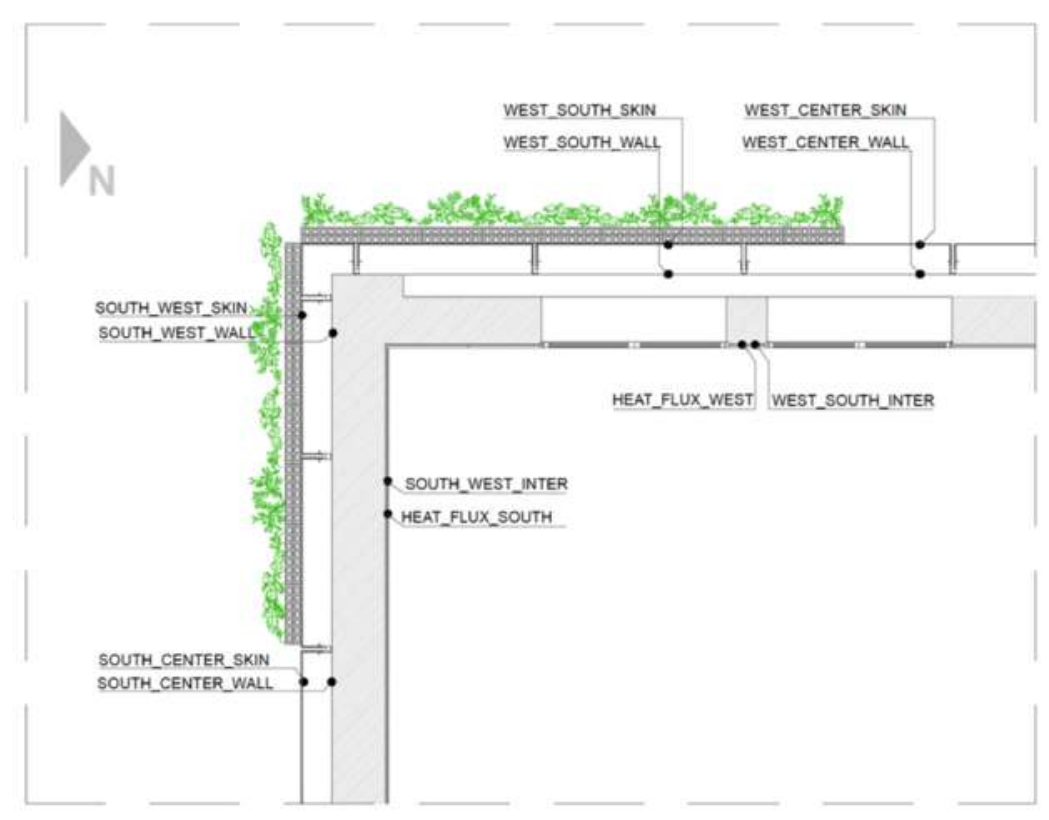

Figure 5 Distribution in plant of the temperature sensors installed on the facade

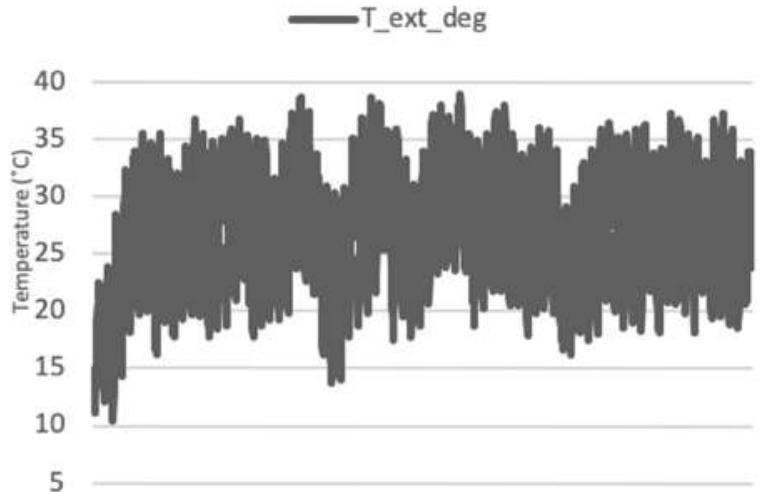

(a)

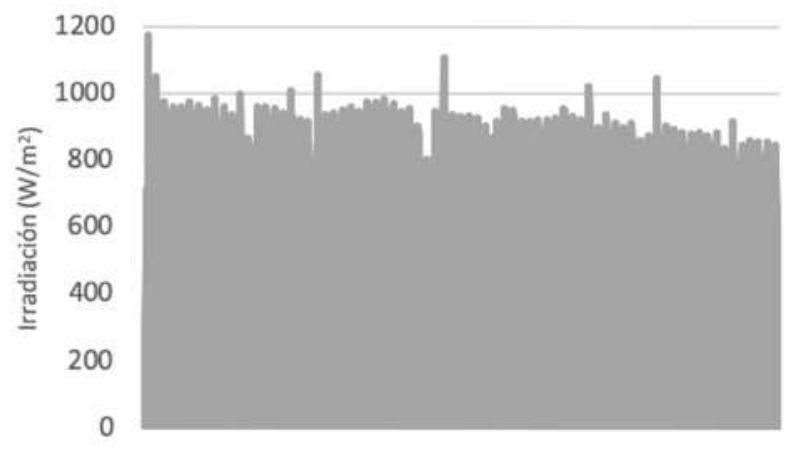

(b)

Figure $\mathbf{6}$ (a) Average temperature during the summer; (b) average irradiance during the summer

average temperatures between $32^{\circ} \mathrm{C}$ and $33,5^{\circ} \mathrm{C}$. The annual thermal amplitude is also high: between 19 and 20 degrees.

To know the most representative days of the year in terms of weather, a study was carried out of the data collected by the weather station located on the roof of the building, which collects data linked to atmospheric pressure $(\mathrm{mmHg})$, outdoor temperature $\left({ }^{\circ} \mathrm{C}\right)$, wind speed $(\mathrm{km} / \mathrm{h})$, wind direction, relative humidity $(\%)$, UV index, irradiation $\left(\mathrm{W} / \mathrm{m}^{2}\right)$ and rainfall $(\mathrm{mm} / \mathrm{h})$.

In this case, irradiation has been selected as the most significant parameter, since solar radiation (Figure 6a) and outdoor temperature (Figure $6 \mathrm{~b}$ ) will be the variables that will most directly influence the behaviour of plant facades.

\subsection{Experimental design and data acquisition}

The real-time monitoring system has been installed through the use of thermocouples, type $\mathrm{K}$ with an error range between $0.1^{\circ} \mathrm{C}$ and $0.3^{\circ} \mathrm{C}$, installed inside and outside the facades, and connected to a distribution system that allows obtaining information every minute, 


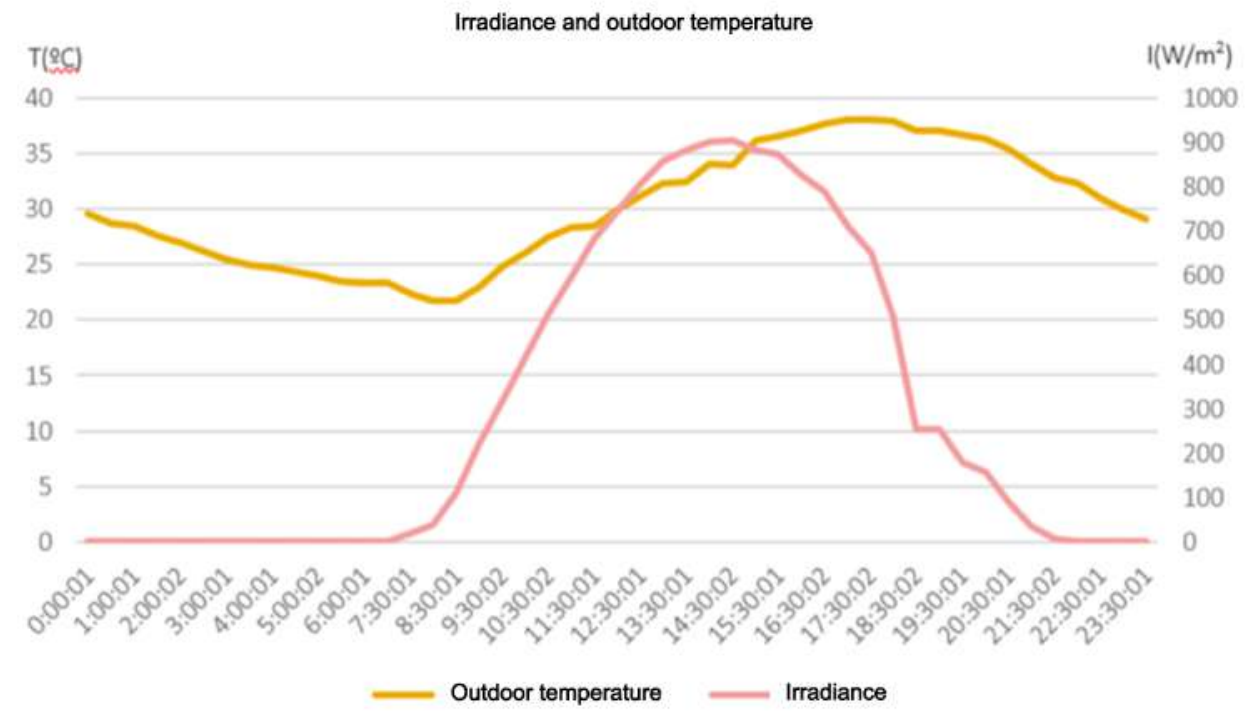

Figure 7 Irradiance and outdoor temperature chart for July 19, 2016

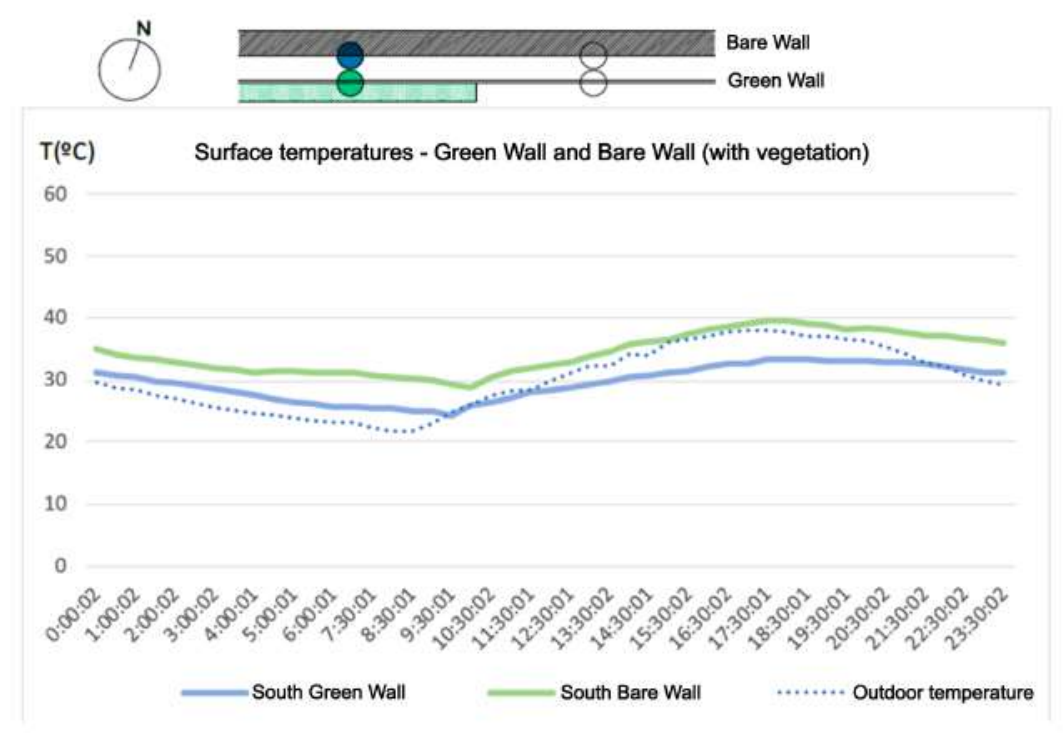

Figure 8 Graph of temperature on the plant facade facing south 


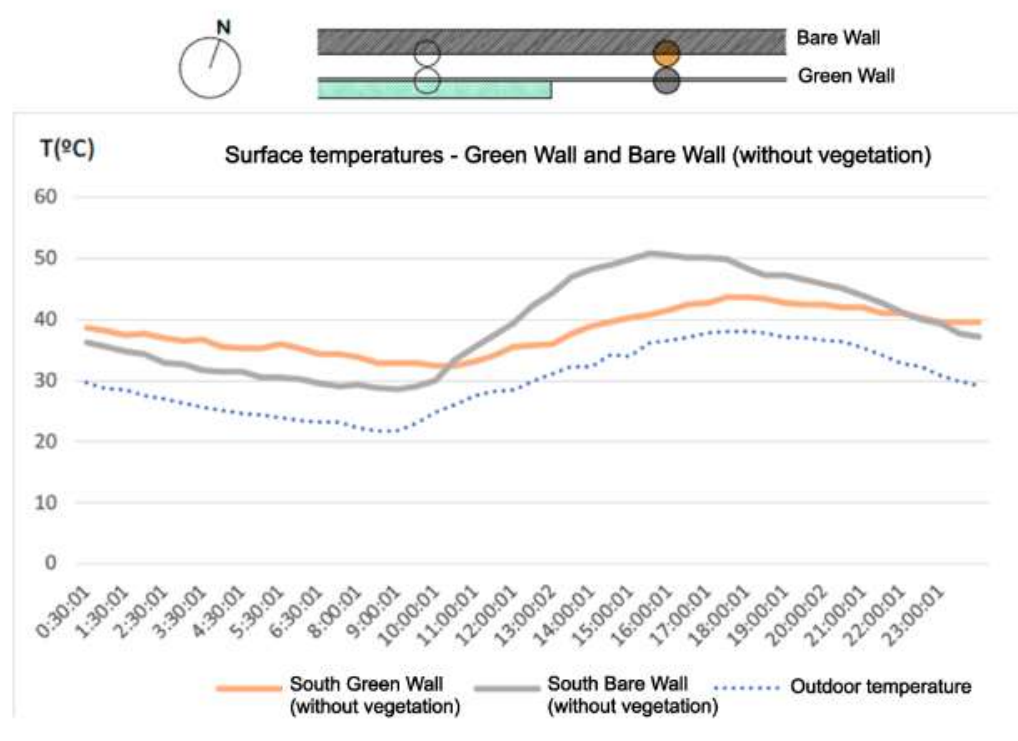

Figure 9 Graph of temperature on the metal envelope facing south

which can be visualized in streaming.

The network of sensors installed in the building is taking data since July 2016, recording the values in one-minute intervals during the twenty-four hours a day. For this reason, the first step in interpreting the data has been to classify them into half-hour intervals. After classification, the previously selected days are evaluated.

To select the most representative days, a database of irradiation data for 12 months, from July 2016 to July 2017 was considered. The objective was to choose the days that represent the majority of the climatic conditions that occur throughout the year in the environment of the vegetal façade. A total of eight typical days were selected, due to the influence it has on the behaviour of vertical gardens:

- Sunny days: 15/07, 19/07, 11/08 and 05/09

- Cloudy days: 20/07, 22/07, 09/08 and 02/09

\subsection{Experimental results}

In the different selected days, the registered values are very similar, consequently this work presents the results of one specific day, a sunny day, which achieve represent the behavior of the facade during the summer.

\section{Sunny day: July 19, 2016}

July 19 has been a sunny summer day, in which the average temperature is $29^{\circ} \mathrm{C}$, with a maximum temperature of $38.1^{\circ} \mathrm{C}$ at $17: 30 \mathrm{~h}$ and a minimum temperature of $21.7^{\circ} \mathrm{C}$ at $8: 30 \mathrm{~h}$. As can be seen in the graph (Figure 7) the solar radiation incident on the building begins at 7:30 am, reaching its maximum at 14:00, where a value of $902 \mathrm{~W} / \mathrm{m}^{2}$ is recorded. From that point on, the radiation begins to decrease, until it becomes null at 21.00h.

To understand the behaviour of the vertical gardens, a study was carried out of the shadows themselves and projected onto the building. It is observed that the modules oriented to the east receive solar radiation during most of the day, except the last hours of the afternoon. For its part, the western façade begins to receive solar radiation at around 11.30 a.m., and from 2.30 p.m. onwards, the shadow of the adjacent building begins to project onto it. From 18:30h, the whole building is in shadow.

In the graph (Figure 8) it is observed the comparison between the temperatures recorded in the wall and the skin in the vegetated zone. It can be noticed how the difference in temperature is constant throughout the day, reaching the greatest difference of $6^{\circ} \mathrm{C}$ at $17.30 \mathrm{~h}$. This difference is due to the ventilated façade and to the fact that the vegetation absorbs part of the solar energy received to carry out photosynthesis. By means of this effect, fresh air is obtained in the interior of the chamber, 
which will serve for aside, to regulate the temperature of the wall, managing to reduce its thermal load. On the other hand, this fresh air is distributed in the façade of the building, achieving a notable reduction of temperatures in the adjacencies of the building, thus improving the microclimatic conditions of the place.

Figure 9 expresses the comparison between the temperatures recorded on the wall and the metal enclosure. At night, with the decrease in outside temperatures, the temperature of the enclosure also decreases considerably. In the same way, as the temperature increases during the day, so does the surface temperature of the enclosure, reaching $50^{\circ} \mathrm{C}$ in the hours of maximum irradiance. In contrast, the wall maintains its temperature constantly, registering maximum differences of $10^{\circ} \mathrm{C}$ throughout the day, as opposed to more than 20 degrees of difference in the metallic mesh.

In general, data analysis allows us to demonstrate that a vertical garden, on a sunny summer day, is capable of absorbing part of the incident solar radiation, achieving a much cooler temperature at the back. On 19 July, at the point of maximum irradiance, an outdoor temperature of $37.7^{\circ} \mathrm{C}$ was recorded, while in the vertical garden it was $38.7^{\circ} \mathrm{C}$, and in the wall area at the back of the garden, it was $32^{\circ} \mathrm{C}$. This allows us to affirm that the temperature of the environment 1.5 meters away from a vertical garden can reduce up to $5^{\circ} \mathrm{C}$ the temperature concerning the temperature of the air, which leads us to conclude that this type of solutions allow us to improve the hygrothermal conditions of the surrounding environment, and affect the energy consumption of the buildings linked to the air conditioning of the spaces.

The main objective of this project was to quantify the benefits in buildings and urban environment provided by the use of green facades. It also aims to contribute to the use of innovative and replicable technologies as possible responses to some of the problems arising from climate change in urban areas, identifying them as adaptation and mitigation strategies. This project is considered to be in line with the thematic priorities of the State Plan for Scientific and Technical Research and Innovation and Programme $\mathrm{H} 2020$ mentioned previously. Likewise, it is considered that the project responds to the guidelines set by the new European programme Horizon Europe and by the new State Research Plan 2021-2027 mentioned in Section 1.1.

\section{Conclusions}

The main objective of the study carried out is to demonstrate the importance of quantifying the benefits of NBS in buildings and the urban environment. At the same time, it proposes the use of innovative and replicable technologies as possible answers to some of the problems derived from climate change in urban areas, identifying adaptation and mitigation strategies.

From the critical evaluation of the current European context and that of the city of Madrid, as well as from the different case studies in development, it is concluded that the potential benefits and beneficiaries of the results of this project are:

The quantification of the effects and benefits of nature-based solutions in urban environments would allow establishing their value and potential as tools to increase the resilience of cities; public administrations, which thanks to the results obtained from the analysis of the monitored data, will be able to have a clear idea of the effectiveness and efficiency of the different systems and thus be able to assess to what extent they could be interesting to be taken into consideration in the development and promotion of local plans for adaptation and mitigation of climate change; the private companies that commercialize the technologies involved in the study will be able to use the analyses carried out to provide potential clients with reliable data on the operation of these technologies; potential investors who, with data in hand, will be able to assess the profitability of the investment.

This research work, based on the study of the social, economic and environmental opportunities offered by solutions based on nature, has allowed us to corroborate the importance of quantifying the associated effects to consolidate the fact that they are tools capable of improving both the conditions of the building in which they are installed and those of their surroundings.

\section{Declaration of competing interest}

We declare that we have no significant competing interests including financial or non-financial, professional, or personal interests interfering with the full and objective presentation of the work described in this manuscript.

\section{Acknowledgements}

The authors would like to thank Luis Hernandez Callejo for the invitation to the Ibero-American Congress of Intelligent Cities (ICSC-CITIES 2019). 


\section{References}

[1] Sustainable development goals. United Nations. Accessed Sep. 2019. [Online]. Available: https://bit.ly/2Ce3kVj

[2] (2018) Seminario UPM: Alinear la investigación con los ODS: Una oportunidad de financiación. Universidad Politécnica de Madrid. Accessed Sep. 2019. [Online]. Available: https://bit.ly/2WjK5AO

[3] (2011) Las ciudades y el cambio climático: Orientaciones para políticas. United Nations Human Settlements Programme. Río de Janeiro, Brasil. [Online]. Available: https://bit.ly/2Wk4WUk

[4] "Sustainable development report 2019," Sustainable Development Solutions Network, New York, USA, Tech. Rep., Jun. 2019.

[5] S. Sassen. (2013, Oct. 24) Los estados se están empobreciendo demasiado. [Online]. Available: https://bit.ly/3j1CNLF

[6] (2019) Transformation, in time EIT climate-KIC strategy 2019-2022. EIT Climate-KIC. Brussels, Belgium. [Online]. Available: https: //bit.ly/2Zrii32

[7] (2019) Call to action: Call for proposals for 2019/2020. EIT Climate-KIC. Brussels, Belgium. [Online]. Available: https://bit.ly/ 3gXzpQ4

[8] M. Mazzucato. (1996, Aug.) Mission-oriented research and innovation in the european union. European Commission. Brussels, Belgium. [Online]. Available: http://www.Amdahl.com/ doc/products/bsg/intra/intra/html

[9] V. Oquendo, A. Sánchez, and L. Olivieri, "Nature based solutions for cities resilience: Opportunities for action in Madrid," in ICSC-CITIES, 2019.

[10] D. Schröter and et al., "Ecosystem service supply and vulnerability to global change in Europe," Science, vol. 310, no. 5752, November 25 2005. [Online]. Available: https://doi.org/10.1126/science.1115233

[11] "Nature-based solutions and re-naturing cities," European Commission, Brussels, Belgium, Tech. Rep., 2015.

[12] "Nature+ : towards nature-based solutions," International Union for Conservation of Nature, Gland, Switzerland, Tech. Rep., 2013.

[13] Horizon 2020. European Commission. Accessed Sep. 2019. [Online]. Available: https://bit.ly/3fufQyv

[14] N. Mestre, "NBS, (no más) soluciones (tan) basadas en la naturaleza: metabolismos, ecosistemas y otra naturaleza envasada," Arquitectura: Revista del Colegio Oficial de Arquitectos de Madrid, no. 375, pp. 46-51, 2018.

[15] C. M. Raymond and et al., "An impact evaluation framework to support planning and evaluation of nature-based solutions projects," EKLIPSE, Wallingford, UK, Tech. Rep., 2017.

[16] S. Charoenkit and S. Yiemwattana, "Living walls and their contribution to improved thermal comfort and carbon emission reduction: A review," Build. Environ., vol. 105, August 152016. [Online]. Available: https://doi.org/10.1016/j.buildenv.2016.05.031

[17] L. Chen, C. Liu, R. Zou, M. Yang, and Z. Zhang, "Experimental examination of effectiveness of vegetation as bio-filter of particulate matters in the urban environment," Environ. Pollut., vol. 208, January 2016. [Online]. Available: https://doi.org/10.1016/j.envpol.2015.09. 006

[18] A. Przybysz, A. Sæbø, H. Hanslin, and S. Gawroński, "Accumulation of particulate matter and trace elements on vegetation as affected by pollution level, rainfall and the passage of time," Sci. Total Environ., vol. 481, May 15 2014. [Online]. Available: https: //doi.org/10.1016/j.scitotenv.2014.02.072

[19] R. Szep and et al., "The dry deposition of PM10 and PM2.5 to the vegetation and its health effect in the ciuc basin," Rev. Chim., vol. 67, no. 4, pp. 639-644, Apr. 2016.

[20] W. Kuttler and A. Strassburger, "Air quality measurements in urban green areas - a case study," Atmos. Environ., vol. 33, no. 24-25, October 1999. [Online]. Available: https://doi.org/10.1016/ S1352-2310(99)00151-X

[21] N. H. Wong and et al., "Thermal evaluation of vertical greenery systems for building walls," Build. Environ., vol. 45, no. 3, March 2010. [Online]. Available: https://doi.org/10.1016/j.buildenv.2009.08.005

[22] L. Mariani and et al., "Climatological analysis of the mitigating effect of vegetation on the urban heat island of Milan, Italy," Sci.
Total Environ., vol. 569, November 01 2016. [Online]. Available: https://doi.org/10.1016/j.scitotenv.2016.06.111

[23] S. Nadia, S. Noureddine, N. Hichem, and D. Djamila, "Experimental study of thermal performance and the contribution of plant-covered walls to the thermal behavior of building," Energy Procedia, vol. 36, 2013. [Online]. Available: https://doi.org/10.1016/j.egypro.2013.07. 113

[24] A. Price, E. C. Jones, and F. Jefferson, "Vertical greenery systems as a strategy in urban heat island mitigation," Water. Air. Soil Pollut., vol. 226, no. 8, July 2015. [Online]. Available: https://doi.org/10.1007/s11270-015-2464-9

[25] I. Karakounos, A. Dimoudi, and S. Zoras, "The influence of bioclimatic urban redevelopment on outdoor thermal comfort," Energy Build., vol. 158, January 01 2018. [Online]. Available: https://doi.org/10.1016/j.enbuild.2017.11.035

[26] A. M. Lacasta, A. Peñaranda, and I. R. Cantalapiedra, "Green streets for noise reduction," in Nature Based Strategies for Urban and Building Sustainability, G. Perez and K. Perini, Eds. Oxford, UK: Butterworth-Heinemann, 2018, pp. 181-190.

[27] N. Fernández, M. Urrestarazu, and D. L. Valera, “Effects of a vertical greenery system on selected thermal and sound mitigation parameters for indoor building walls," J. Food, Agric. Environ., vol. 10, no. 3, pp. 1025-1027, Jul. 2012.

[28] R. Bullen and F. Fricke, "Sound propagation through vegetation," J. Sound Vib., vol. 80, no. 1, January 08 1982. [Online]. Available: https://doi.org/10.1016/0022-460X(82)90387-X

[29] T. Renterghem, D. Botteldooren, and K. Verheyen, "Road traffic noise shielding by vegetation belts of limited depth," J. Sound Vib., vol. 331, no. 10, May 07 2012. [Online]. Available: https: //doi.org/10.1016/j.jsv.2012.01.006

[30] M. Hornikx and T. Renterghem, "The potential of vegetation for reducing road traffic noise at urban quiet sides," in $9^{\text {th }}$ European conference on noise control, Prague, Czech Republic, 2012, pp. 949-954.

[31] A. Afshari, "A new model of urban cooling demand and heat island-application to vertical greenery systems (VGS)," Energy Build., vol. 157, December 15 2017. [Online]. Available: https: //doi.org/10.1016/j.enbuild.2017.01.008

[32] D. H. S. Duarte, P. Shinzato, C. Santos, and C. A. Alves, "The impact of vegetation on urban microclimate to counterbalance built density in a subtropical changing climate," Urban Clim., vol. 14, December 2015. [Online]. Available: https://doi.org/10.1016/j.uclim.2015.09. 006

[33] C. Jim and H. He, "Estimating heat flux transmission of vertical greenery ecosystem," Ecol. Eng., vol. 37, no. 8, August 2011. [Online]. Available: https://doi.org/10.1016/j.ecoleng.2011.02.005

[34] T. A. Moya, A. Dobbelsteen, M. Ottelé, and P. M. Bluyssen, "A review of green systems within the indoor environment," Indoor Built Environ., vol. 28, no. 3, 2019. [Online]. Available: https://doi.org/10.1177/1420326X18783042

[35] C. Bartesaghi, P. Osmond, and A. Peters, "Evaluating the cooling effects of green infrastructure: A systematic review of methods, indicators and data sources," Sol. Energy, vol. 166, May 152018. [Online]. Available: https://doi.org/10.1016/j.solener.2018.03.008

[36] P. M. F. Wouw, E. J. M. Ros, and H. J. H. Brouwers, "Precipitation collection and evapoltranspilration of living wall systems: A comparative study between a panel system and a planter box system," Build. Environ., vol. 126, December 2017. [Online]. Available: https://doi.org/10.1016/j.buildenv.2017.10.002

[37] E. Cubi, N. F. Zibin, S. J. Thompson, and J. Bergerson, "Sustainability of rooftop technologies in cold climates: Comparative life cycle assessment of white roofs, green roofs, and photovoltaic panels," Journal of Industrial Ecology, vol. 20, no. 2, March 2015. [Online]. Available: https://doi.org/10.1111/jiec.12269

[38] Z. Azkorra and et al., "Evaluation of green walls as a passive acoustic insulation system for buildings," Appl. Acoust., vol. 89, March 2015. [Online]. Available: https://doi.org/10.1016/j.apacoust.2014.09.010

[39] I. Susorova, M. Angulo, P. Bahrami, and B. Stephens, "A model of vegetated exterior facades for evaluation of wall thermal performance," Build. Environ., vol. 67, September 2013. [Online]. 
Available: https://doi.org/10.1016/j.buildenv.2013.04.027

[40] F. Olivieri, D. Redondas, L. Olivieri, and J. Neila, "Experimental characterization and implementation of an integrated autoregressive model to predict the thermal performance of vegetal façades," Energy Build., vol. 72, April 2014. [Online]. Available: https://doi.org/10.1016/j.enbuild.2013.12.062

[41] J. Alonso, F. Olivieri, J. Neila, and C. Bedoya, "Hygrothermal performance of vegetation on cladding and translucent facade systems," in $27^{\text {th }}$ Conference on Passive and Low Energy Architecture, Louvain-la-Neuve, Belgium, 2011, pp. 13-15.

[42] A. M. Omer, "Renewable building energy systems and passive human comfort solutions," Renew. Sustain. Energy Rev., vol. 12, no. 6, August 2008. [Online]. Available: https://doi.org/10.1016/j.rser.2006.07.010

[43] C. Nesshöver and et al., "The science, policy and practice of nature-based solutions: An interdisciplinary perspective," Sci. Total Environ., vol. 579, February 01 2017. [Online]. Available: https://doi.org/10.1016/j.scitotenv.2016.11.106

[44] P. Sukhdev and et al. The economics of ecosystems and biodiversity: Mainstreaming the economics of nature: A synthesis of the approach, conclusions and recommendations of TEEB. The Economics of Ecosystems and Biodiversity. Geneva, Switzerland. [Online]. Available: https://bit.ly/20t21Eo

[45] D. J. Teece, "Business models, business strategy and innovation," Long Range Plann., vol. 43, no. 2-3, April 2010. [Online]. Available: https://doi.org/10.1016/j.lrp.2009.07.003

[46] A. Osterwalder, Y. Pigneur, and C. L. Tucci, "Clarifying business models: Origins, present, and future of the concept," Commun.
Assoc. Inf. Syst., vol. 16, 2005. [Online]. Available: https://doi.org/10. 17705/1CAIS.01601

[47] N. J. Foss and T. Saebi, "Fifteen years of research on business model innovation: How far have we come, and where should we go?" J. Manage., vol. 43, no. 1, November 2016. [Online]. Available: https://doi.org/10.1177/0149206316675927

[48] The New Urban Agenda, Habitat III Secretariat, United Nations, 2017.

[49] The city of Zagreb development strategy for the period leading up to 2020. City of Zagreb. Zagreb, Croatia. [Online]. Available: https://bit.ly/3fz9k9G

[50] Paris Resilience Strategy, Mairie de Paris.

[51] "Emissions reduction plan for our operations 2016 - 2021," City of Melbourne, Melbourne, Australia, Tech. Rep., 2016.

[52] C. Tapia and et al. (2015, Jul.) Análisis de vulnerabilidad ante el cambio climático en el municipio de Madrid. Tecnalia Research \& Innovation. Madrid, Spain. [Online]. Available: https://bit.ly/20pldSy

[53] Madrid + natural. soluciones naturales para adaptarnos al cambio climático. Medio ambiente y movilidad de Madrid. Madrid, Spain. [Online]. Available: https://bit.ly/3iZeHRP

[54] Plan a: Plan de calidad del aire y cambio climático de la ciudad de madrid. Ayuntamiento de Madrid. Madrid, Spain. [Online]. Available: https://bit.ly/307KHKU

[55] Sistema biofiver. Vertiarte. Accessed Sep. 2019. [Online]. Available: https://bit.ly/3j7xn1Q

[56] HOBO MX2301A temperature/RH data logger. ONSET. Accessed Sep. 2019. [Online]. Available: https://bit.ly/2B34d2C 